RECEBIDO EM: 06/06/2016

Aprovado EM: 15/09/2016

\title{
A RESPONSABILIDADE CIVIL DO ESTADO POR INEFICIÊNCIA NA PRESTAÇÃO DO SERVIÇO PÚBLICO DE SAÚDE: UMA ANÁLISE À LUZ DA TEORIA DA FAUTE DU SERVICE
}

CIVIL LIABILITY OF THE STATE BY THE INEFFICIENCY ON THE PROVISION OF THE PUBLIC HEALTH SERVICE: AN ANALYSIS IN LIGHT OF FAUTE DU SERVICE THEORY

Rennan Gustavo Ziemer da Costa

Mestrando em Direito do Estado pela Universidade Federal do Paraná. Especialista em Direito Administrativo pelo Instituto de Direito Romeu Felipe Bacellar. Pesquisador do NINC-UFPR.

Bárbara Marianna de Mendonça Araújo Bertotti Mestranda em Direito Econômico e Desenvolvimento na Pontifícia Universidade Católica do Paraná. Especialista em Direito Público pela Escola da Magistratura Federal do Paraná e em Direito Administrativo pelo Instituto de Direito Romeu Felipe Bacellar. Pesquisadora do NINC-UFPR e do NUPED-PUCPR. 
SUMÁRIO: Introdução; 1 A reserva do (financeiramente) possível como restrição à eficácia do direito fundamental à saúde; 2 O Sistema Único de Saúde (SUS) e a diretriz de atendimento integral; 3 Responsabilidade objetiva do Estado e a teoria da faute du service; 4 Responsabilidade civil (ou patrimonial) do Estado por ineficiência na prestação do serviço público de saúde; 5 Conclusões; Referências.

RESUMO: A Constituição Federal de 1988 ao reconhecer expressamente o direito à saúde como direito fundamental da pessoa humana atribuiu à Administração Pública o dever de concretizá-lo por meio do respectivo serviço público, diretamente ou através de terceiros, sem excluir a iniciativa privada desta atividade. Todos os entes da federação têm o dever de prestar o serviço público de saúde. Sabe-se também, que a saúde básica deve ser disponibilizada à toda população (universalização do acesso ao bem jurídico). Diante disso, o presente trabalho propõe analisar, à luz da teoria da faute du service, as hipóteses de responsabilização civil do Estado decorrentes de condutas imputadas ao Estado nos casos de ineficiência do serviço público de saúde, por mau funcionamento, não funcionamento ou funcionamento tardio. Para tanto, devem ser atendidos os seguintes pressupostos: (i) descumprimento de um dever jurídico concreto de agir (omissão) ou cumprimento precário (ação) por parte do Estado ou de quem lhe faça as vezes; (ii) ocorrência de dano a um cidadão; e (iii) nexo de causalidade entre o comportamento estatal e o prejuízo sofrido. Além disso, a responsabilização patrimonial do Estado por omissão na área da saúde depende de um dever específico de agir que apenas pode ser constatado na análise do caso concreto e deve ter por pressuposto a legislação específica e demais atos normativos. Por fim, cabe ressaltar que apenas é responsável pela reparação do dano o ente estatal que o causou.

PALAVRAS-CHAVE: Direito Fundamental à Saúde. Serviço Público de Saúde. Responsabilidade Civil do Estado. Teoria da Faute Du Service.

ABSTRACT: The Federal Constitution of 1988 in recognizing expressly the right to health as fundamental right of human dignity assigned to the Public Administration a duty to concretize it by means of the respective public service, directly or through third parties, without excluding the private enterprise from this activity. All the entities of the federation have a duty to provide the public health service. It is also known that basic health services must be available to all the population (universalization of access to legal interest). Thus, the present paper proposes to analyze, in light of 
faute du service theory, the hypotheses of civil liability of the State resulting from conducts imputed to the State in the cases of inefficiency of the public health service, due to malfunctioning, non-functioning or late functioning. Therefore, the following assumptions must be followed: (i) noncompliance of a concrete legal duty to act (omission) or precarious observance (action) by the State or who represents it; (ii) occurrence of damage to a citizen; and (iii) causal link between the state behavior and the harm suffered. Furthermore, the State patrimonial responsibility for omission in health area depends on a specific duty of acting, that may only be found in the analysis of the concrete case and must have as a presupposition the specific legislation and other normative acts. At last, it is worth pointing out that the only responsible for undoing the damage is the state entity that has caused it.

KEYWORDS: Fundamental Right to Health. Public Health Service. Civil Liability of the State. Faute Du Service Theory.

\section{INTRODUÇÃO}

No Brasil, o direito à saúde foi incluído expressamente no rol dos direitos fundamentais pela primeira vez na Constituição Federal de 1988. Sendo assim, comunga da dupla fundamentalidade-formal e material- da qual são revestidos os direitos e garantias fundamentais da nossa ordem jurídico-constitucional ${ }^{1}$. No entanto, para além de sua condição de direito fundamental, a saúde é também dever. Tal afirmação decorre do próprio texto constitucional, que em seu art. 196 assegura que "a saúde é direito de todos e dever do Estado...”.

O direito à saúde impõe ao Estado tanto obrigações positivas (deveres de proteção e promoção) quanto negativas (dever de respeito). Trata-se da perspectiva jurídico-objetiva dos direitos fundamentais. Já a perspectiva jurídico-subjetiva garante direito subjetivo aos titulares, autorizandoos a reclamarem em juízo determinada ação ou omissão ${ }^{2}$. Com relação

1 SARLET, Ingo Wolfgang. A eficácia dos direitos fundamentais: uma teoria geral dos direitos fundamentais na perspectiva constitucional. 10 ed. revista, atualizada e ampliada. Porto Alegre: Livraria do Advogado, 2011. p.74.

2 CLÈVE, Clèmerson Merlin. A eficácia dos direitos fundamentais sociais. In: BACELLAR FILHO, Romeu Felipe; GABARDO, Emerson; HACHEM, Daniel Wunder (Coord.). Globalização, direitos fundamentais e direito administrativo: novas perspectivas para o desenvolvimento econômico e socioambiental: Anais do I Congresso da Rede Docente Eurolatinoamericana de Direito Administrativo. Belo Horizonte: Fórum, 2011. p. 100. Daniel Wunder Hachem afirma que a fusão entre as dimensões objetiva e subjetiva das normas garantidoras de direitos fundamentais permite perceber sua multifuncionalidade. Para o autor, "quando observado o direito fundamental em sentido amplo, ele se desdobra em várias funções: (i) de defesa contra investidas do Estado; (ii) de prestações materiais, 
à titularidade do direito fundamental à saúde, o art. $5^{\circ}$, caput, da Carta Maior dispõe que os direitos e garantias fundamentais nela consagrados são assegurados aos brasileiros e estrangeiros residentes no país ${ }^{3}$. Ingo Sarlet, contudo, assevera que a norma do já citado art. $196^{34}$ excepciona a regra geral estabelecida no caput do art. $5^{\circ}$, cristalizando assim o princípio da universalidade.

Desse modo, como direito fundamental da pessoa humana ${ }^{5}$, o direito à saúde integra o rol dos direitos sociais e compõe a segunda dimensão (ou geração) dos direitos fundamentais, marcando a mudança do Estado de Direito de inspiração liberal-burguesa para o Estado Social de Direito ${ }^{6}$. Vale ressaltar que a instrumentalização dos direitos sociais se dá por meio do serviço público ${ }^{7}$.

fornecidas no mundo dos fatos; (iii) de prestações normativas, ligadas à proteção do direito fundamental contra ações de outros particulares e à criação de órgãos, instituições e procedimentos que viabilizem de forma universalizada o desempenho das demais funções”. HACHEM, Daniel Wunder. A dupla titularidade (individual e transindividual) dos direitos fundamentais econômicos, sociais, culturais e ambientais. Revista de Direitos Fundamentais e Democracia, v. 14, n. 14, Curitiba, p. 618-688, jul./dez. 2013, p. 627-628. Clèmerson Clève acrescenta ainda a função da não discriminação, onde o Estado deve colocar os bens e serviços à disposição do cidadão de maneira igualitária e não discriminatória (exceto aquelas necessárias para cumprir o princípio da igualdade).

3 Caso este dispositivo seja interpretado literalmente, excluiria os estrangeiros não residentes no Brasil do âmbito de proteção do direito à saúde. Ingo Sarlet, contudo, ressalta que a interpretação desse dispositivo não deve ser restritiva. SARLET, Ingo Wolfgang. Algumas considerações em torno do conteúdo, eficácia e efetividade do direito à saúde na Constituição de 1988. Interesse Público - IP, Sapucaia do Sul, ano 3, n. 12, p. 91-107, out./dez. 2001. p.96.

4. Art. 196 da CF: "A saúde é direito de todos e dever do Estado, garantido mediante políticas sociais e econômicas que visem à redução do risco de doença e de outros agravos e ao acesso universal e igualitário às ações e serviços para sua promoção, proteção e recuperação".

Os direitos fundamentais se sujeitam a um regime específico de princípios e regras. Na Constituição brasileira, os dois elementos de maior destaque que integram esse regime especial são a aplicabilidade imediata $\left(\operatorname{art.} 5^{\circ}, \S 1^{\circ}\right)$ e a proteção contra reformas constitucionais abolitivas (art. 60, $\$ 4^{\circ}$, IV). SARLET, op. cit., 2011. p. 66-67. SARLET, op. cit., 2001. p. 97.

7 Daniel Wunder Hachem leciona que os quatro motivos da fundamentalidade material do direito fundamental ao serviço público são: (i) não há como se garantir o acesso a todos os titulares dos direitos sociais sem que o Estado preste serviços públicos; (ii) sem a prestação do serviço público adequado, o conteúdo dos direitos sociais do art. $6^{\circ}$ se esvaziaria; (iii) está previsto expressamente em documentos internacionais, como na Declaração Americana dos Direitos e Deveres do Homem, entre outros; (iv) decorre diretamente dos princípios da dignidade da pessoa humana e da cidadania (art. $1^{\circ}$, II e III, CF), pois os serviços públicos são indispensáveis para proporcionar aos cidadãos condições de existência digna e possibilitar sua participação ativa na comunidade política e social, além de serem imprescindíveis para atingir os objetivos fundamentais da República de erradicar a pobreza, reduzir as desigualdades sociais, garantir o desenvolvimento e construir uma sociedade livre, justa e solidária (art. $3^{\circ}$, I a III, CF). HACHEM, Daniel Wunder. Direito fundamental ao serviço público adequado e capacidade econômica do cidadão: repensando a universalidade do acesso à luz da igualdade material. $A \Xi^{\circ} \mathrm{C}-$ Revista de Direito Administrativo \&ٔ Constitucional, Belo Horizonte, ano 14, n. 55, p. 123-158, jan./mar. 2014. p.132-133. 
A Constituição Federal atribuiu ao Poder Público o dever de concretizar o direito à saúde, diretamente ou através de terceiros, inclusive pessoas físicas ou jurídicas de direito privado. É o que prevê art. $197^{8}$. Ademais, todos os entes da federação têm o dever de prestar o serviço público de saúde. O Dec. 7.508/2011, que regulamenta a Lei 8.080/1990 (conhecida por Lei Orgânica da Saúde), em seu art. 33 estabelece que o acordo de colaboração entre os entes federativos para a organização da rede interfederativa de atenção à saúde será firmado por meio de Contrato Organizativo da Ação Pública da Saúde. Este "contrato organizativo" define as responsabilidades de cada ente federativo, os critérios de avaliação de desempenho e os recursos financeiros a serem demandados. A partir deste instrumento, é possível, nos casos de omissão administrativa, verificar se a conduta é ilegal e qual ente seria responsável por ela9 .

Diante disso, propõe o presente trabalho analisar, à luz da teoria da faute du service, a possibilidade de responsabilização do Estado, na esfera cível, nos casos de ineficiência no serviço público de saúde, seja por ação (mau funcionamento) ou omissão (não funcionamento ou funcionamento tardio), desde que atendidos os pressupostos que serão expostos. Desde já, impende destacar que em ambos os casos a responsabilidade do Estado é objetiva. Antes, porém, serão tratados aspectos relativos à fundamentalidade do direito à saúde, a saber: a possível restrição de sua eficácia por meio da cláusula da "reserva do possível" e sua efetivação por meio do Sistema Único de Saúde (SUS), notadamente no que tange à diretriz de atendimento integral.

\section{A RESERVA DO (FINANCEIRAMENTE) POSSÍVEL COMO RESTRIÇÃO À EFICÁCIA DO DIREITO FUNDAMENTAL À SAÚDE}

Antes de se analisar o art. $5^{\circ}$, $1^{010}$, da Constituição de 1988, convém fazer uma distinção entre os conceitos de eficácia jurídica e eficácia social. A primeira está vinculada à possibilidade de a norma produzir efeitos

\footnotetext{
Para aprofundamento no tema ver: SCHIER, Adriana da Costa Ricardo. Regime jurídico do serviço público: garantia fundamental do cidadão e proibição de retrocesso social. Curitiba, 2009. 224 f. Tese (Doutorado em Direito) - Programa de Pós-Graduação em Direito, Universidade Federal do Paraná, 2009. Adriana Schier defende que a prestação do serviço público como instrumento de concretização dos direitos sociais só será possível se tal atividade for prestada de forma universal, contínua e com tarifa módica, consagrando-se, assim, o núcleo essencial do regime jurídico previsto no art. $6^{\circ}, \$ 1^{\circ}$, da Lei no 8.987 , de 1995. f. 151 .

8 Art. 197 da CF: "São de relevância pública as ações e serviços de saúde, cabendo ao Poder Público dispor, nos termos da lei, sobre sua regulamentação, fiscalização e controle, devendo sua execução ser feita diretamente ou através de terceiros e, também, por pessoa física ou jurídica de direito privado”.

9 PIVETTA, Saulo Lindorfer. Direito fundamental à saúde: regime jurídico, políticas públicas e controle judicial. São Paulo: Revista dos Tribunais, 2014. p. 136.

10 Art. $5^{\circ}, \$^{\circ}$ da CF: "As normas definidoras dos direitos e garantias fundamentais têm aplicação imediata".
} 
jurídicos. Assim, a eficácia jurídica se relaciona com a aplicabilidade e com a potencial exigibilidade da norma. Já a eficácia social corresponde à noção de efetividade, baseada na concreta observância da norma no plano fático.

Partindo da classificação de José Afonso da Silva em: (i) normas de eficácia plena - aquelas que desde a sua entrada em vigor produzem todos os efeitos essenciais, não dependendo de regulamentação, (ii) normas de eficácia contida - que tem eficácia plena mas podem ser objeto de restrição pelo legislador infraconstitucional, e (iii) normas de eficácia limitada - a produção plena de efeitos depende de ação do legislador ou de outros órgãos estatais, poderia se cogitar que todas as normas de direitos fundamentais são de eficácia plena, e portanto, não restringíveis. No entanto, embora todos os direitos fundamentais sejam dotados de algum nível de eficácia e aplicabilidade, este não será o mesmo para todos os direitos, em todas as funções que possa exercer ${ }^{11}$. Com isso, percebe-se que os direitos fundamentais muitas vezes reclamam a intervenção concretizadora do Estado, em especial do legislador. Para Virgílio Afonso da Silva, "não existe norma constitucional que não dependa de algum tipo de regulamentação e que não seja suscetível de algum tipo de restrição"12.

A partir disso, percebe-se que a aplicação das normas de direitos fundamentais não deve ser feita sob a lógica do tudo ou nada (típico das normas-regra), proposta por Robert Alexy ${ }^{13}$. Há dois grupos de normas definidoras de direitos fundamentais: (i) aquelas que, possuindo nível suficiente de normatividade, se mostram aptas a produzirem seus efeitos de forma plena; e (ii) aquelas que que dependem de uma intervenção regulamentadora para produzirem plenamente seus efeitos ${ }^{14}$. Sendo assim, e partindo do pressuposto da natureza principiológica do art. $5^{\circ}, \$^{\circ}$ da CF/1988, é necessário a análise do caso concreto para saber se a norma está apta (ou não) a produzir efeitos ${ }^{15}$.

Em suma, pode-se afirmar que a necessidade de regulamentação infraconstitucional dos comandos normativos pelos poderes Legislativo e Executivo salienta a ideia de que podem ser impostas restrições, reservas

\footnotetext{
11 PIVETTA, op. cit., p.50.

12 SILVA, Virgílio Afonso da. Direitos Fundamentais: conteúdo essencial, restrições e eficácia. São Paulo: Malheiros, 2009. p. 230.

13 ALEXY, Robert. Teoría de los derechos fundamentales. Madrid: Centro de Estudios Constitucionales, 2007. p. $82-86$

14 SARLET, 2011, p. 270.

15 Ibidem, p. 271.
} 
à sua aplicabilidade ${ }^{16}$. Nessa esteira, Jorge Reis Novais indica que as reservas que incidem em geral são as seguintes: reserva imanente de ponderação, reserva do politicamente adequado ou oportuno e reserva do financeiramente possível. A indicação de cada uma dependerá de qual dever estatal está em causa (dever de respeito, dever de proteção, dever de promoção $)^{17}$. No presente estudo, analisaremos detidamente a reserva do financeiramente possível (ou mais comumente utilizada no Brasil, "reserva do possível”), ligada aos deveres de promoção e proteção do direito.

Quando se trata de uma dimensão positiva, há a necessidade de alocação direta de recursos pelo Estado ${ }^{18}$. Saulo Pivetta assevera que "a necessidade de recursos financeiros não fulmina a jusfundamentalidade do direito à saúde"19. Afirma ainda, o autor, que "essa reserva deve ser compreendida não como um obstáculo intransponível para a realização de prestações fáticas, mas sim como um fator que direciona para a forma como os recursos são alocados para o cumprimento das finalidades do Estado"20.

A expressão "reserva do possível" originou-se de uma decisão do Tribunal Constitucional Alemão, que versava sobre o acesso de um estudante ao ensino superior (caso numerus clausus Entscheidung) e foi utilizada com a finalidade de se afirmar que o conteúdo dos direitos sociais estava limitado "àquilo que o indivíduo podia razoavelmente exigir da sociedade" ${ }^{\prime 2}$. Nesse caso, o Tribunal Alemão entendeu existirem limitações fáticas para o atendimento de todas as demandas de acesso a um direito ${ }^{22}$.

Com entendimento distinto, foi recepcionado no Brasil pela doutrina e jurisprudência como três formas de limitação: fática, jurídica e de

16 PIVETTA, op. cit., p. 68.

17 NOVAIS, Jorge Reis. Direitos sociais: teoria jurídica dos direitos sociais enquanto direitos fundamentais.

Coimbra: Coimbra, 2010. p. 221-227.

18 Ingo Sarlet, contudo, afirma que todos os direitos fundamentais podem implicar "um custo", e não apenas os direitos sociais de cunho prestacional. FIGUEIREDO, Mariana Filchtiner; SARLET, Ingo Wolfgang. Reserva do possível, mínimo existencial e direito à saúde: algumas aproximações. In: SARLET, Ingo Wolfgang; TIMM, Luciano Benetti (org.). Direitos Fundamentais: orçamento e "reserva do possível". 2. ed. revista e ampliada. Porto Alegre: Livraria do Advogado, 2013. p. 28.

19 PIVETTA, op. cit., p. 74

20 Ibidem, p. 74. Paulo Caliendo afirma haver uma reserva do possível geral no Brasil chamada dívida pública, que impede os gastos sociais. CALIENDO, Paulo. Reserva do possível, direitos fundamentais e tributação. In: SARLET, Ingo Wolfgang; TIMM, Luciano Benetti (org.). Direitos Fundamentais: orçamento e "reserva do possível". 2. ed. revista e ampliada. Porto Alegre: Livraria do Advogado, 2013. p. 182.

21 NOVAIS, op. cit., p. 278.

22 CALIENDO, op. cit., p. 180. 
razoabilidade ${ }^{23}$. A limitação fática consiste na possibilidade financeira do Estado (falta de recursos); a jurídica consiste na capacidade do

Estado de dispor dos recursos existentes (orçamentária) ${ }^{24}$; e a razoabilidade está ligada ao fato de se é (ou não) razoável que o cidadão exija do Estado a prestação do direito ${ }^{25}$. Relevante citar que a insuficiência de recursos, quando alegada, deve ser provada, sob pena de responsabilização do administrador ${ }^{26}$.

Desde o caso "Terrier", em 1903, o Conselho de Estado Francês decidiu que o Estado não poderia se eximir de seus deveres alegando falta de disponibilidade de caixa. Romeu Felipe Bacellar Filho, analisando a problemática da responsabilidade extracontratual do Estado, afirmou que não se pode invocar a teoria da reserva do possível para excluir ou atenuar a responsabilidade estatal. ${ }^{27} \mathrm{Com}$ isso, vê-se que apesar da relevância do aspecto financeiro, nem sempre a reserva do possível pode ser ativada ${ }^{28}$.

Neste ponto, impende citar a expressiva decisão do Supremo Tribunal Federal na Arguição de Descumprimento a Preceito Fundamental n ${ }^{\circ} 45$, com relatoria de Celso de Mello, pela qual, por um lado, a reserva do possível é admitida como cláusula impeditiva da exigibilidade judicial do conteúdo integral dos direitos sociais, visto a limitação material do Estado, ligada

23 GLOECKNER, Joseane Ledebrum. A reserva do possível como limite à efetividade do direito fundamental à saúde. $A \mathcal{E}^{2} \mathrm{C}-$ Revista de Direito Administrativo $\mathcal{E}^{2}$ Constitucional, Belo Horizonte, ano 13 , n. 51, p. 233-250, jan./mar. 2013. p. 237.

24. O gasto com o direito prestacional deverá estar previsto no orçamento público anual.

25 Ingo Sarlet sustenta que a reserva do possível possui dimensão tríplice: (i) a da efetiva disponibilidade fática dos recursos; (ii) a da disponibilidade jurídica dos recursos materiais e humanos (distribuição de receitas e competências orçamentárias, tributárias, legislativas, administrativas, entre outros); e (iii) a da perspectiva do particular que demanda a prestação material, de maneira que se verifique a proporcionalidade e a razoabilidade da conduta pleiteada. FIGUEIREDO; SARLET, op. cit., p. 30.

$\mathrm{O}$ art. 373, II do Novo Código de Processo Civil dispõe que incumbe ao réu o ônus da prova quanto à existência de fato impeditivo, modificativo ou extintivo do direito do autor.

27 BACELlar FIlHO, Romeu Felipe. Direito Administrativo e o novo Código Civil. Belo Horizonte: Fórum, 2007. p. 243. Saulo Pivetta justifica o fato de não poder ser invocada a reserva do possível para afastar ou restringir a jusfundamentalidade do direito a saúde ou de qualquer direito social, tendo em vista que os direitos de liberdade (nas hipóteses de proteção e promoção) também podem reclamar o dispêndio de recursos financeiros do Estado. PIVETTA,op. cit., p. 77.

28 José Reinaldo de Lima Lopes sustenta que a alegação da reserva do possível é legítima nos casos de litígios de direito público, especialmente quando o pedido e a decisão tenham o intuito de beneficiar alguém em particular e de forma imediata e isolada. LOPES, José Reinaldo de Lima. Em torno da reserva do possível. In: SARLET, Ingo Wolfgang; TIMM, Luciano Benetti (org.). Direitos Fundamentais: orçamento e “reserva do possivel”. 2. ed. revista e ampliada. Porto Alegre: Livraria do Advogado, 2013. p. 172-173. 
a sua possibilidade orçamentária; e por outro lado, o Estado não pode invocá-la para eximir-se do cumprimento de seus deveres constitucionais, principalmente quando da omissão "puder resultar nulificação ou, até mesmo, aniquilação de direitos constitucionais impregnados de um sentido de essencial fundamentalidade”. ${ }^{29}$

Saulo Pivetta, ao tratar da reserva do possível como possível restrição à aplicabilidade do direito fundamental à saúde, afirma que a escassez de recursos deve ser vista de maneira moderada (jamais absoluta), visto a significativa arrecadação tributária do Brasil. Paulo Caliendo leciona que a tributação tanto pode funcionar como um fator de alargamento da reserva do possível - na medida em que são criados tributos como modelo de financiamento de direitos fundamentais sociais - quanto um fator de diminuição da mesma - quando parte da arrecadação é desviada para financiar outros elementos diversos dos direitos fundamentais ou se perde no custeio de uma máquina pública ${ }^{30}$. Assim, resta se verificar a adequada alocação de recursos para as finalidades constitucionais e infraconstitucionais ${ }^{31}$.

É obrigação de todos os órgãos estatais e agentes políticos a tarefa de maximizar os recursos e minimizar o impacto da reserva do possível. A partir disso, depreende-se que a reserva do possível deve ser encarada com cautela e que as limitações vinculadas a ela não são necessariamente falaciosas. O que o é, contudo, é a maneira como ela tem sido invocada para impedir intervenção judicial e servir de desculpa genérica para a omissão estatal na seara da efetividade dos direitos fundamentais. ${ }^{32}$

Neste contexto, é relevante tratar do conceito de "mínimo existencial", de inspiração doutrinária e jurisprudencial alemã, que "pretende atribuir ao indivíduo um direito subjetivo contra o Poder Público, que seria obrigado a garantir uma existência mínima digna a todos os cidadãos”3.

29 BRASIL. Supremo Tribunal Federal. Medida Cautelar na Arguição de Descumprimento de Preceito

Fundamental $n^{\circ} 45$. Relator Ministro Celso de Mello, julgado em 29.04.2004. DJ, publicado em 04.05.2004.

CALIENDO, op. cit., p. 184-185.

PIVETTA, op. cit., p. 78.

BARRETO, Vicente de Paulo. Reflexões sobre os direitos sociais. Revista Quaestio Iuris, [S.1.], v. 04, nº 01, 2011. p. 488-512. A jurisprudência reconheceu critérios normativos para definir se a prestação requerida consubstancia ou não direito subjetivo do reclamante. São eles: (i) reconhecimento da comunidade científica quanto à eficácia do remédio/tratamento pleiteado (ou a comprovação de que o medicamento se encontra devidamente registrado na Anvisa, o que faz pressupor a sua eficácia; (ii) adequação do remédio/tratamento para a pessoa do requerente; (iii) inexistência de outro medicamento/tratamento igualmente eficaz, 
Esse conceito apresenta problemática acerca da indeterminabilidade do quantum a ser por ele assegurado. Daniel Wunder Hachem afirma existirem duas correntes doutrinárias distintas quanto à fixação deste conteúdo: (i) a que defende haver um "conteúdo determinável no caso concreto", para a qual os limites do mínimo existencial só poderão ser delimitados analisando-se as circunstâncias fáticas do caso concreto; e (ii) a que sustenta haver um "rol constitucional preferencial", onde o conteúdo do mínimo existencial pode ser definido a partir de um elenco preferencial oferecido pela Constituição, considerando as peculiaridades do momento histórico considerado. Divergindo da maioria da doutrina, Hachem se alinha à segunda corrente, argumentando que ao se aceitar um conceito completamente aberto de mínimo existencial, o intérprete pode variá-lo indiscriminadamente, conforme o caso concreto, prejudicando assim a funcionalidade operacional do instituto. ${ }^{34}$

Ana Paula de Barcellos assevera que "as prestações que fazem parte do mínimo existencial - sem o qual restará violado o núcleo da dignidade da pessoa humana, compromisso fundamental do Estado brasileiro- são oponíveis e exigíveis dos poderes públicos constituídos”. Para a autora, o mínimo existencial é composto de quatro elementos: a educação básica, a saúde básica, a assistência aos desamparados (de caráter instrumental) e o acesso à justiça. As prestações da "saúde básica" são diferenciadas das demais a partir de dois parâmetros: a relação entre o custo da prestação de saúde e o benefício que ela poderá proporcionar para o maior número de pessoas, ou seja, tem preferência a prestação de saúde capaz de, pelo menor custo, atender de maneira eficaz o maior número de pessoas; e a inclusão prioritária ao mínimo existencial das necessidades passadas, presentes e futuras de todos os indivíduos. ${ }^{35}$

A Constituição de 1988, nesta linha, deu prioridade a quatro ações: (i) a prestação do serviço de saneamento (art. 23, IX, 198, II e 200, IV); (ii) $\mathrm{o}$ atendimento materno-infantil (art. $\left.227, \$ 1^{\circ}, \mathrm{I}\right)$; (iii) as ações de medicina preventiva (art. 198, II); e (iv) as ações de prevenção epidemiológica (art.

constante das políticas do SUS; (iv) o medicamento/tratamento tenha sido prescrito por profissional médico habilitado (preferencialmente credenciado ao SUS); (v) o requerente não disponha de condições financeiras para arcar com o medicamento/tratamento sem comprometer seu sustento e o de sua família.

34 HACHEM, Daniel Wunder. Mínimo existencial e direitos fundamentais econômicos e sociais: distinções e pontos de contato à luz da doutrina e jurisprudência brasileiras. In: BACELLAR FILHO, Romeu Felipe; HACHEM, Daniel Wunder (Coord.). Direito público no Mercosul: intervenção estatal, direitos fundamentais e sustentabilidade. Belo Horizonte: Fórum, 2013. p. 213- 215. 
200, II). ${ }^{36}$ As prestações de saúde básica devem ser fornecidas pelo Estado a toda população (universalização do acesso ao bem jurídico). Para as demais prestações, exigese a intervenção do legislador ordinário ${ }^{37}$.

No ordenamento jurídico brasileiro, contudo, o conteúdo do direito à saúde assume contornos bem delineados, visto o extenso rol de leis ordinárias e atos administrativos neste campo, que integram a própria norma constitucional do direito à saúde, submetidos ao regime jurídico especial dos direitos fundamentais. ${ }^{38}$

\section{O SISTEMA ÚNICO DE SAÚDE (SUS) E A DIRETRIZ DE ATENDIMEN- TO INTEGRAL}

A Constituição Federal de 1988, em seu art. 198 dispõe que "as ações e serviços públicos de saúde integram uma rede regionalizada e hierarquizada e constituem um sistema único(...)”. Com isso, tem-se que, no Brasil, a efetivação do direito à saúde se dá por meio do Sistema Único de Saúde (SUS), que "representa o núcleo estruturante de todas as ações e serviços de saúde pública"’39. Este sistema modificou completamente a política sanitária brasileira, antes voltada apenas para dois objetivos: (i) para fazer frente a situações emergenciais, muitas vezes com o uso do aparato policial; e (ii) para manter a integridade física do trabalhador ${ }^{40}$.

O SUS trata-se de estrutura complexa, da qual participam vários atores: órgãos da Administração Pública direta (como o Ministério da Saúde, Secretarias Estaduais e Municipais), entes da Administração Indireta (como a Agência Nacional de Vigilância Sanitária e os hospitais universitários vinculados às universidades públicas), pessoas de direito privado (como Organizações Sociais e hospitais filantrópicos) e os Conselhos e Conferências de Saúde, que viabilizam a participação comunitária na formulação e gestão das políticas públicas sanitárias ${ }^{41}$. A atuação de todos

\footnotetext{
36 Ibidem, p. 320-329.

37 Para aprofundamento no tema, ver: BARCELLOS, Ana Paula. O direito a prestações de saúde: complexidades, mínimo existencial e o valor das abordagens coletiva e abstrata. In: SOUZA NETO, Cláudio Pereira; SARMENTO, Daniel (coord.). Direito sociais: fundamentos, judicialização e direitos sociais em espécie. Rio de Janeiro: Lumen Juris, 2008. p. 807-815. 
estes agentes se dá de maneira articulada, a partir de diretrizes traçadas constitucionalmente. ${ }^{42}$

Primeiramente, o caput do art. 198 da $\mathrm{CF} / 1988$ estabelece que as ações e serviços públicos de saúde integram uma rede regionalizada e hierarquizada. A partir disso, tem-se que a divisão do sistema se dá por circunscrições regionais, que além dos critérios geográficos leva em conta também as peculiaridades de cada região e suas demandas na área da saúde. A hierarquização, por sua vez, ocorre pela ordenação dos serviços a partir de sua complexidade, graduados em três níveis: o atendimento primário, $\mathrm{o}$ atendimento secundário e o atendimento terciário ${ }^{43}$.

Além disso, os incisos do art. 198 listam três diretrizes do Sistema Único de Saúde: (i) descentralização, com direção única em cada esfera de governo; (ii) atendimento integral, com prioridade para as atividades preventivas, sem prejuízo dos serviços assistenciais; e (iii) participação da comunidade ${ }^{44}$. Para a finalidade traçada neste trabalho, se analisará detalhadamente apenas a diretriz do atendimento integral.

42 PIVETTA, op. cit., p. 125.

43 Trata-se de modelo recomendado pela Organização Mundial de Saúde e pela Organização Panamericana de Saúde, por viabilizar um planejamento mais adequado e uma maior eficiência na gestão dos recursos públicos. $\mathrm{O}$ atendimento primário (ou atenção básica) envolve as ações de baixa complexidade (como consultas simples). A partir daí, quando necessário, o cidadão é encaminhado (referenciado) para os níveis mais complexos (secundário ou terciário). PIVETTA, op. cit., p. 125-126. A atenção básica é capaz de resolver $80 \%$ dos problemas de saúde da população, conforme indicado na cartilha "Entendendo o SUS". Disponível em: <http://portalsaude.saude.gov.br/images/pdf/2013/agosto/28/cartilha-entendendo-osus-2007.pdf> Acesso em: 01 nov. 2015.

44 $\mathrm{O}$ art. $7^{\circ}$ da lei 8.080/1990 dispõe que, além das diretrizes previstas no art. 198 da CF, as ações e serviços públicos de saúde e os serviços privados contratados ou conveniados que integram o Sistema Único de Saúde (SUS), obedecem ainda aos seguintes princípios: I - universalidade de acesso aos serviços de saúde em todos os níveis de assistência; II - integralidade de assistência, entendida como conjunto articulado e contínuo das ações e serviços preventivos e curativos, individuais e coletivos, exigidos para cada caso em todos os níveis de complexidade do sistema; III - preservação da autonomia das pessoas na defesa de sua integridade física e moral; IV - igualdade da assistência à saúde, sem preconceitos ou privilégios de qualquer espécie; V - direito à informação, às pessoas assistidas, sobre sua saúde; VI - divulgação de informações quanto ao potencial dos serviços de saúde e a sua utilização pelo usuário; VII - utilização da epidemiologia para o estabelecimento de prioridades, a alocação de recursos e a orientação programática; VIII - participação da comunidade; IX - descentralização político-administrativa, com direção única em cada esfera de governo :a) ênfase na descentralização dos serviços para os municípios; b) regionalização e hierarquização da rede de serviços de saúde; X - integração em nível executivo das ações de saúde, meio ambiente e saneamento básico; XI - conjugação dos recursos financeiros, tecnológicos, materiais e humanos da União, dos Estados, do Distrito Federal e dos Municípios na prestação de serviços de assistência à saúde da população; XII - capacidade de resolução dos serviços em todos os níveis de assistência; e XIII organização dos serviços públicos de modo a evitar duplicidade de meios para fins idênticos. 
O art. $6^{\circ}$ da Lei 8.080/1990 (Lei Orgânica da Saúde) lista um extenso rol de obrigações incluídas na esfera de abrangência do SUS ${ }^{45}$, com o intuito de atender à exigência da integralidade. A referida lei, em seu art. $7^{\circ}$, II, especificou que a integralidade na assistência é "entendida como conjunto articulado e contínuo das ações e serviços preventivos e curativos, individuais e coletivos, exigidos para cada caso em todos os níveis de complexidade do sistema". Vale ressaltar que "o conteúdo do direito à saúde assegurado pela Constituição compreende todas as dimensões de eficácia típicos dos direitos fundamentais, impondo ao Estado deveres de respeito, de proteção e de promoção". ${ }^{46}$

A partir disso, a Norma Operacional Básica do SUS (NOB 1/96), formalizada através da Portaria n ${ }^{\circ} 2.203$ do Ministério da Saúde, sistematiza o atendimento das demandas pessoais e das exigências ambientais em três áreas: (i) a da assistência, em que as atividades são dirigidas às pessoas, individual ou coletivamente, e que é prestada no âmbito ambulatorial e hospitalar, bem como em outros espaços, especialmente no domiciliar; (ii) a das intervenções ambientais (em sentido mais amplo, que inclui as relações e as condições sanitárias nos ambientes de vida e de trabalho, o controle de vetores e hospedeiros e a operação de sistemas de saneamento ambiental); e (iii) a das políticas externas ao setor saúde, que interferem nos determinantes sociais do processo saúde-doença das coletividades, de que são partes importantes questões relativas às políticas macroeconômicas, ao emprego, à habitação, à educação, ao lazer e à disponibilidade e qualidade dos alimentos.

Percebe-se, nesse contexto, que a diretriz de atendimento integral do SUS deve englobar medidas preventivas (prioritariamente ${ }^{47}$ ) e assistenciais.

45 Art. $6^{\circ}$ da Lei 8080/1990: "Estão incluídas ainda no campo de atuação do Sistema Único de Saúde (SUS):I - a execução de ações: a) de vigilância sanitária; b) de vigilância epidemiológica; c) de saúde do trabalhador; e d) de assistência terapêutica integral, inclusive farmacêutica; II - a participação na formulação da política e na execução de ações de saneamento básico; III - a ordenação da formação de recursos humanos na área de saúde; IV - a vigilância nutricional e a orientação alimentar; V - a colaboração na proteção do meio ambiente, nele compreendido o do trabalho; VI - a formulação da política de medicamentos, equipamentos, imunobiológicos e outros insumos de interesse para a saúde e a participação na sua produção; VII - o controle e a fiscalização de serviços, produtos e substâncias de interesse para a saúde; VIII - a fiscalização e a inspeção de alimentos, água e bebidas para consumo humano; IX - a participação no controle e na fiscalização da produção, transporte, guarda e utilização de substâncias e produtos psicoativos, tóxicos e radioativos; X - o incremento, em sua área de atuação, do desenvolvimento científico e tecnológico; XI - a formulação e execução da política de sangue e seus derivados".

Art. 198, II da CF: “As ações e serviços públicos de saúde integram uma rede regionalizada e hierarquizada e constituem um sistema único, organizado de acordo com as seguintes diretrizes: II - atendimento integral, com prioridade para as atividades preventivas, sem prejuízo dos serviços assistenciais”. 
A integralidade, portanto, deve ser compreendida como a obrigação do Poder Público formular políticas públicas que, a partir de critérios epidemiológicos e científicos, englobem as ações e serviços necessários à garantia da saúde física, mental e social de todos os cidadãos. Logo, não significa que toda e qualquer prestação assistencial integra o conteúdo do direito à saúde exigível do Estado. ${ }^{48}$

Os critérios epidemiológicos utilizados pelo Ministério da Saúde se dividem em quatro frentes: (i) análise da situação de saúde; (ii) identificação de perfis e fatores de risco; (iii) vigilância em saúde; e (iv) avaliação epidemiológica de serviços, ações e programas ${ }^{49}$. Com relação ao critério científico, este deverá ser observado para que um determinado medicamento, produto ou tratamento passe a integrar as políticas do $\mathrm{SUS}^{50}$.

O art. 19-M da Lei Orgânica da Saúde dispõe que a integralidade consiste em: (i) dispensação de medicamentos e produtos de interesse para a saúde, cuja prescrição esteja em conformidade com as diretrizes terapêuticas definidas em protocolo clínico para a doença ou o agravo à saúde a ser tratado; (ii) oferta de procedimentos terapêuticos, em regime domiciliar, ambulatorial e hospitalar, constantes de tabelas elaboradas pelo gestor federal do Sistema Único de Saúde - SUS, realizados no território nacional por serviço próprio, conveniado ou contratado.

Antes de se adentrar no próximo tópico, se faz necessário tratar dos Protocolos Clínicos e Diretrizes Terapêuticas (PCDT), já que os serviços e bens de saúde entregues pelo Estado devem estar de acordo com as previsões dos mesmos. São definidos como: "documento que estabelece critérios para o diagnóstico da doença ou do agravo à saúde; o tratamento preconizado, com os medicamentos e demais produtos apropriados, quando couber; as posologias recomendadas; os mecanismos de controle clínico; e o acompanhamento e a verificação dos resultados terapêuticos, a serem seguidos pelos gestores do SUS ${ }^{\prime \prime 1}$.

Essa delimitação do conteúdo do direito à saúde se faz necessária por duas razões: (i) para assegurar a diretriz da universalidade do SUS,

48 PIVETTA, op. cit., p.130.

49 Ibidem, p.131.

50 Art. 19-Q, $\S 2^{\circ}$, I da Lei 8.080/1990: "O relatório da Comissão Nacional de Incorporação de Tecnologias no SUS levará em consideração, necessariamente: I - as evidências científicas sobre a eficácia, a acurácia, a efetividade e a segurança do medicamento, produto ou procedimento objeto do processo, acatadas pelo órgão competente para o registro ou a autorização de uso".

51 Art. 19-N, II da Lei Orgânica da Saúde. 
o tratamento ofertado em um caso específico deve ser disponibilizado a qualquer cidadão que tenha a mesma necessidade; (ii) a ausência de protocolos inviabilizaria qualquer planejamento logístico, diminuindo a eficiência da gestão administrativa das ações e serviços de saúde ${ }^{52}$. Cabe ao Ministério da Saúde promover a incorporação, exclusão ou alteração dos PCDT, juntamente com a Comissão Nacional de Incorporação de Tecnologia do SUS, que oferecerá apoio técnico ${ }^{53}$. Contudo, caso se verifique a ineficiência do tratamento neles previsto, ou a ausência de protocolo clínico para a situação, é possível que o médico receite medicamento ou tratamento adequado ao paciente, ainda que não previsto na diretriz, sob pena de se violar a diretriz de atendimento integral. As demais restrições impostas, no entanto, devem ser mantidas ${ }^{54}$.

O Decreto 7.508/2011 institui a Relação Nacional de Ações e Serviços de Saúde (Renases) e a Relação Nacional de Medicamentos (Rename), pelos quais deverão ser publicizadas as prestações que são fornecidas pelo Sistema Único de Saúde.

\section{RESPONSABILIDADE OBJETIVA DO ESTADO E A TEORIA DA FAUTE DU SERVICE}

A responsabilidade do Estado no Brasil está prevista no art. 37, $\S 6^{\circ}$, da Constituição Federal, assim redigido: "as pessoas jurídicas de direito público e as de direito privado prestadoras de serviços públicos responderão pelos danos que seus agentes, nessa qualidade, causarem a terceiros, assegurado o direito de regresso contra o responsável nos casos de dolo ou culpa" ${ }^{\prime 5}$. Desse dispositivo infere-se que a responsabilidade entre o Estado e a vítima será objetiva, e entre o Estado e o agente causador do dano, subjetiva.

Emerson Gabardo afirma que "a responsabilização decorre da especialidade do regime jurídico imposto, e, portanto, é perfeitamente

52 PIVETTA, op. cit., p. 150.

53 Art. 19-Q da Lei Orgânica da Saúde.

54. O art. 19-T da Lei Orgânica da Saúde veda expressamente a dispensação de medicamentos sem registro na Anvisa, bem como proíbe o pagamento ou ressarcimento de produto ou procedimento experimental, ou de uso não autorizado pela agência.

55 Romeu Felipe Bacellar Filho defende que a locução serviço público constante no $\$ 6^{\circ}$ do art. 37 da Constituição não deve ser interpretada em seu sentido técnico, mas deve abranger a responsabilidade objetiva do Estado também no exercício da função legislativa e jurisdicional, no fomento, no poder de polícia, no poder disciplinar e, com fundamento no art. 927 do Código Civil, inclusive na atuação de empresas públicas que exerçam atividade econômica geradora de riscos. BACELLAR FILHO, op. cit., p. 228-231. 
justificável o seu caráter objetivo...” ${ }^{56}$. No entanto, tanto a doutrina quanto a jurisprudência flexibilizam o rigor constitucional, adotando posicionamentos diversos.

Conforme ensina Romeu Felipe Bacellar Filho, "a responsabilidade patrimonial da Administração Pública advém do descumprimento ao disposto em cláusulas contratuais, ou da conduta humana comissiva ou omissiva, lícita ou ilícita, lesiva a interesses juridicamente protegidos, estranha a qualquer ajuste, podendo ser contratual ou extracontratual" 57 . Ao contrário do Direito Civil, no Direito Administrativo também se admite responsabilização patrimonial por atos lícitos com fundamento no princípio da distribuição igualitária dos ônus e encargos sociais ${ }^{58}$.

O Estado é responsável apenas por danos causados pelos agentes públicos no exercício de suas funções ${ }^{59}$. Fora de suas atividades, há apenas responsabilidade da pessoa física com fundamento no Direito Civil ${ }^{60}$.

Caso o ente político não preste diretamente o serviço público, mas disponibilize esta comodidade mediante descentralização administrativa ou por concessão à iniciativa privada, estas pessoas jurídicas são imediatamente responsáveis pelos danos que causarem. Caso tornem-se insolventes, deve ser acionado o agente público responsável pelo dano e, sucessivamente, arcará com a indenização a União, o Estado ou Município apenas se os outros não puderem reparar o dano. A responsabilidade subsidiária se justifica porque a obrigação originária de prestar o serviço é do próprio Estado ${ }^{61}$.

56 GABARDO, Emerson. Responsabilidade objetiva do Estado em face dos princípios da eficiência e da boafé. In: FERRAZ, Luciano; MOTTA. Fabricio (Org.). Direito Público Moderno, Belo Horizonte: Del Rey, 2003. p. 261-262.

57 Ibidem, p. 197.

58 GUERRA, Alexandre Dartanhan de Mello. Hipóteses de não incidência de responsabilidade civil do Estado. In: GUERRA, Alexandre Dartanhan de Mello; PIRES, Luis Manuel Fonseca; BENACCHIO, Marcelo (coord.). Responsabilidade civil do Estado: Desafios contemporâneos. São Paulo: Quartier Latin, 2010. p. 303-305.

Bacellar Filho defende a ordem de preferência na responsabilidade, afastando a solidariedade. Assim, primeiro se responsabiliza o prestador do serviço público e depois o agente (pessoa física) em caso de dolo ou culpa, pois a Constituição impõe esta ordem. BACELLAR FILHO, Romeu Felipe. Direito Administrativo e o novo Código Civil. Belo Horizonte: Fórum, 2007. p. 235.

60 HACHEM, Daniel Wunder. Responsabilidade civil do Estado por omissão: uma proposta de releitura da teoria da faute du service. In: MARQUES NETO, Floriano de Azevedo et al (org.). Direito e Administração Pública: Estudos em homenagem a Maria Sylvia Zanella Di Pietro. São Paulo: Atlas, 2013. p. 1137. 
De acordo com Marcos Blasi, o Supremo Tribunal Federal vem categoricamente rejeitando a possibilidade de responsabilização direta do agente público, ou seja, primeiro se aciona o Estado que, se condenado, deve ingressar com ação regressiva ${ }^{62}$. Além do cidadão beneficiado pelo serviço público, o STF, em sede de repercussão geral, admitiu inclusive o dever de indenizar terceiro não usuário do serviço sem necessidade de demonstração de culpa, ainda que prestado por pessoa jurídica de direito privado ${ }^{63}$.

Tratando-se de dano decorrente de ato ilícito, o dever de indenizar decorre da inobservância ao princípio da legalidade. Por outro lado, quando o Estado age com observância à lei, há hipóteses em que o dano é presumido, como na desapropriação, e outras em que o dano é acidental, cuja recomposição se fundamenta no princípio da igualdade ${ }^{64}$.

A doutrina da faute du service, segundo Daniel Wunder Hachem, se aplica nos casos em que o serviço público causa dano por ação (funcionou mal) ou por omissão (não funcionou ou funcionou atrasado). $\mathrm{O}$ autor indica a existência de divergência na doutrina sobre a responsabilidade por omissão, se depende da demonstração do dolo ou culpa ou apenas do nexo causal entre a inércia da Administração e o dano ${ }^{65}$.

Celso Antônio Bandeira de Mello sustenta que a responsabilidade estatal por ação, fundada na teoria do risco-proveito, é objetiva e a por omissão é subjetiva, pois nesta hipótese o dano não seria causado pelo Estado. A inércia seria mera condição, dependendo da constatação de dolo ou culpa estatal decorrente da abstenção de impedir o dano, apesar da existência de dever legal de agir. Defende a presunção de culpa do Poder Público, por imprudência, imperícia e negligência, com a possibilidade de

62 BLASI, Marcos Chucralla Moherdaui. Panorama atual da responsabilidade do Estado em matéria de serviços públicos na jurisprudência do STF. Revista Brasileira de Direito Público, Belo Horizonte, ano 8, n. 31, out./dez. 2010. p. 100-101.

BRASIL. Supremo Tribunal Federal. Recurso Extraordinário no 591874, Relator Ministro Ricardo Lewandowski. Tribunal Pleno, julgado em 26.08.2009. DJe-172, divulgado em 11.09.2009, publicado em 14.09.2009.

64 NOHARA, Irene Patrícia. Direito Administrativo. 5. ed. São Paulo: Atlas, 2015. p. 792-795.

65 HACHEM, Daniel Wunder. Responsabilidade civil do Estado por omissão: uma proposta de releitura da teoria da faute du service. In: MARQUES NETO, Floriano de Azevedo; ALMEIDA, Fernando Dias Menezes de; NOHARA, Irene Patrícia; MARRARA, Thiago (Org.). Direito e Administração Pública: estudos em homenagem a Maria Sylvia Zanella Di Pietro. São Paulo: Atlas, 2013. p. 1132-1133. 
prova em contrário. Ou seja, a demonstração que não agiu com dolo ou culpa afasta a responsabilidade estatal ${ }^{66}$.

A responsabilidade por ação estatal não enseja maiores divergências jurisprudenciais e doutrinárias quanto ao seu caráter objetivo. Hachem, ao analisar a doutrina sobre as origens da faute du service, atesta que esta teoria, da forma que foi elaborada na França, é compatível com a responsabilidade objetiva ${ }^{67}$. Acerca da doutrina da teoria nos casos de omissão, o autor constata que os doutrinadores franceses "referem-se ao fato objetivo de inobservância de um dever juridicamente imposto"68 não às modalidades de culpa (negligência, imprudência ou imperícia), ou seja, faute não deve ser traduzido como culpa, pois não é este o sentido utilizado na França.

Defende, ainda, que a utilização da teoria da faute du service para os casos em que o serviço público não funcionou, funcionou mal ou funcionou atrasado, em sua origem francesa, não importa responsabilidade subjetiva, já que se admite a responsabilidade objetiva do Estado por atos omissivos naquele país. Sustenta, ainda, que a qualificação da responsabilidade da Administração deve observar o respectivo ordenamento jurídico que, no caso brasileiro, por força da Constituição Federal, impõe um regime que dispensa a demonstração de dolo ou culpa ${ }^{69}$.

À luz do princípio da proporcionalidade, não havendo motivos suficientes para tratar de maneira distinta as ações e as omissões estatais quando afetem o núcleo dos direitos fundamentais, Juarez Freitas também se posiciona a favor da responsabilidade objetiva ${ }^{70}$. Defende a inversão do ônus da prova do nexo de causalidade, não a culpa presumida ${ }^{71}$.

66 MELLO, Celso Antônio Bandeira de. Curso de Direito Administrativo. 25 ed. São Paulo: Malheiros, 2008. p. 996-1001.

67 Em sentido contrário, Rodrigo Valgas dos Santos entende que há contradição na adoção da teoria da faute du service, que dependeria da demonstração da culpa ou dolo, com a responsabilidade objetiva. SANTOS,

Rodrigo Valgas dos. Nexo causal e excludentes da responsabilidade extracontratual do Estado. In:

FREITAS, Juarez (org.). Responsabilidade civil do Estado. São Paulo: Malheiros, 2006. p. 273.

68 HACHEM, Daniel Wunder. HACHEM, Daniel Wunder. Responsabilidade civil do Estado por omissão: uma proposta de releitura da teoria da faute du service. In: MARQUES NETO, Floriano de Azevedo; ALMEIDA, Fernando Dias Menezes de; NOHARA, Irene Patrícia; MARRARA, Thiago (Org.). Direito e Administração Pública: estudos em homenagem a Maria Sylvia Zanella Di Pietro. São Paulo: Atlas, 2013. p. 1139.

69 Ibidem, p. 1139. No mesmo sentido: NOHARA, op. cit., p. 832; BACELLAR FILHO, op. cit., p. 213.

70 FREITAS, Juarez. Omissão administrativa e o teste de proporcionalidade. Interesse Público, Belo Horizonte, ano 15 , n. 78 , , p. 20 , mar./abr. 2013.

71 Ibidem, p. 25. 
Rodrigo Valgas dos Santos afirma que "para imputarmos ao Estado a responsabilização objetiva, por ação ou omissão, a tarefa que de súbito se impõe ao operador jurídico é verificar se há ou não o nexo entre a conduta e o resultado danoso" ${ }^{2}$. Explica, o autor, que não se deve confundir causalidade com culpabilidade, pois pode haver nexo causal sem culpa, como nos casos de responsabilidade estatal por atos lícitos ${ }^{73}$. "O nexo causal é a indispensável relação de causa e efeito para que o dano possa ser juridicamente relevante" 74 .

A adoção da teoria publicista objetiva é mais adequada, pois exige a demonstração do nexo causal entre o dano e a conduta estatal e permite a aplicação de excludentes de responsabilidade, impedindo que o Estado se transforme em segurador universal ${ }^{75}$.

À primeira vista, a efetiva diferença entre a responsabilidade subjetiva e objetiva por atos omissivos pode passar despercebida, pois "a 'culpa genérica' ou prestação deficiente de serviços públicos de que fala a teoria subjetiva acaba tendo o mesmo efeito prático do não cumprimento do dever legal"76. Ocorre que a adoção da responsabilidade subjetiva por atos omissivos acaba por chancelar o descumprimento do dever estatal de eficiência (art. 37, caput, da Constituição Federal), reflexo do direito fundamental à boa administração.

Não pode o Poder Público ficar desonerado de arcar com indenização caso não se prepare razoavelmente para o cumprimento do dever legal de impedir o dano sob a alegação de ausência de dolo ou culpa na sua conduta. Esta postura afronta o princípio da igualdade dos cidadãos perante os encargos públicos. A teoria objetiva é mais abrangente que a subjetiva justamente nestas hipóteses de descumprimento do dever de eficiência.

A doutrina elaborou diversas teorias sobre o nexo causal. De acordo com a teoria da equivalência das condições, também conhecida como conditio sine qua non, importada do Direito Penal, toda causa que hipoteticamente excluída evitasse a ocorrência do dano seria de igual importância para a verificação do dever de indenizar. Esta não é a opção

\footnotetext{
72 SANTOS, op. cit., p. 269.

73 Ibidem, p. 271.

74. Ibidem, p. 270

75 Ibidem, p. 272.

76 BLASI, op. cit., p. 99.
} 
adotada no Brasil ${ }^{77}$. "O ponto fraco da teoria é considerar todas as condições como equivalentes, sem distinguir, na cadeia causal, quais fatos foram mais ou menos relevantes na produção do resultado"78.

A teoria da causalidade adequada é menos radical. Analisa se a causa hipoteticamente é apta ou não para produzir o dano conforme o curso natural das coisas, ou seja, sem a existência de uma circunstância extraordinária determinante para a produção do dano ${ }^{79}$. Esta teoria apresenta uma vertente positiva, onde o evento será causa do dano sempre que for "consequência natural" ou "efeito provável" na sequência dos fatos geraram o resultado danoso; e outra negativa, que inversamente considera que caso o fato danoso seja indiferente na produção do resultado, ele não será causa $^{80}$. Rodrigo Valgas dos Santos esclarece que esta teoria acaba por deixar a juízo do julgador a discricionariedade de decidir o que é ou não causa adequada em razão da dificuldade prática de se constatar esta circunstância ${ }^{81}$.

Por fim, a teoria dos danos diretos e imediatos, ou teoria da interrupção do nexo causal, segundo a qual não importa o tempo transcorrido entre a causa e o dano, mas que a causa seja necessária para a ocorrência do dano, ou seja, se o dano decorre direta e imediatamente da causa ${ }^{82}$. Havendo mais de uma condição que possa se enquadrar como causa, ambas seriam aptas a gerar o dever de indenizar ${ }^{83}$.

Analisadas sumariamente as teorias do nexo causal, se faz necessário o estudo das suas excludentes. A primeira é o fato da vítima, em que foi o próprio lesado que se expôs indevidamente ao risco criado pelo Estado. Não há a necessidade que seja fato exclusivo da vítima ou que esta aja com dolo ou culpa.

A análise do caso concreto é fundamental para a averiguação se a contribuição da vítima foi realmente determinante para a geração do dano $^{84}$. Se o fato contribuiu apenas em parte para ocorrência do dano,

\footnotetext{
77 SANTOS, op. cit., p. 275-276.

78 Ibidem, p. 275.

79 Ibidem, p. 276-277.

80 Ibidem, p. 277.

81 Ibidem, p. 279.

82 Ibidem, p. 279.

83 Ibidem, p. 281.

84 Ibidem, p. 285-286.
} 
não há exclusão, mas atenuação da responsabilidade ${ }^{85}$, conforme art. 945 do Código Civil ${ }^{86}$. De qualquer forma, o ônus da prova do fato da vítima, por ser fato desconstitutivo, incumbe ao Estado ${ }^{87}$.

O fato de terceiro também pode romper o nexo causal quando o dano não foi gerado nem pela vítima nem pelo Estado. Quando há concorrência de causas do dano, o terceiro também será responsável, cabendo ao Estado a prova desta excludente do nexo causal, seja integralmente ou como atenuante. Ressalte-se que em geral os particulares não estão sujeitos à responsabilização objetiva. Inexistindo dolo ou culpa em sua conduta, o dever de indenizar será integralmente do Estado ${ }^{88}$.

Também o caso fortuito e a força maior, que se caracterizam por fatos imprevisíveis, quanto à efetiva ocorrência ou ao momento que aconteçam, mas primordialmente por serem inevitáveis ainda que o Estado seja diligente. Depreende-se do parágrafo único do art. 393 do Código Civil que não há distinção legal entre estas figuras jurídicas ${ }^{89}$. Não se pode alegar estas excludentes por falta de manutenção das estruturas físicas a cargo do Estado ou do prestador de serviço público, ou seja, se houver culpa ${ }^{90}$ ou omissão a um dever razoavelmente exigível.

Juarez Freitas também considera excludente do nexo causal a impossibilidade de cumprimento do dever, devidamente justificada, que não se confunde com a mera arguição de reserva do possível ${ }^{91}$.

Romeu Felipe Bacellar Filho acrescenta o estado de necessidade, que pode afastar ou diminuir a responsabilidade quando houver prevalência do interesse público sobre o privado ${ }^{92}$. Pode ocorrer em caso de calamidade pública em que o Poder Público requisita bens privados ou ocupa-os temporariamente, cabendo indenização apenas se ocorrer danos anormais, conforme art. $5^{\circ}$, XXV, da Constituição Federal.

\footnotetext{
85 FREITAS, op. cit., p. 19.

86 GUERRA, op. cit., p. 296.

87 Ibidem, p. 328.

88 SANTOS, op. cit., p. 286-287.

89 GUERRA, op. cit., p. 318.

90 Ibidem, p. 319.

91 FREITAS, op. cit., p. 19.

92 BACELLAR FILHO, op. cit., p. 243.
} 
A mera privação da disponibilidade de um bem ou serviço não acarreta dever de indenizar, desde que caracterizado o "iminente perigo público”. Ausente esta circunstância, não há estado de necessidade, logo o cerceamento da propriedade privada sem justa causa deve ser indenizado.

\section{RESPONSABILIDADE CIVIL (OU PATRIMONIAL) DO ESTADO POR INEFICIÊNCIA NA PRESTAÇÃO DO SERVIÇO PÚBLICO DE SAÚDE}

Emerson Gabardo e Daniel Hachem afirmam haver ineficiência no comportamento administrativo quando este for: (i) omisso, por descumprir um dever de agir estatuído para a Administração Pública; (ii) moroso, por desrespeitar o dever de celeridade; (iii) exacerbadamente formalista, por obstaculizar uma atuação ágil e fluida, marcada pela simplicidade e objetividade; (iv) perdulário, por ignorar o dever de otimização dos recursos para o alcance dos melhores resultados; e (v) improdutivo, por violar o dever de realização dos objetivos previstos pela lei para o atingimento efetivo do interesse público. ${ }^{93} \mathrm{Em}$ todos os casos, independentemente de ação ou omissão, a responsabilidade é objetiva.

Para que haja responsabilização do Estado por violação ao princípio da eficiência são necessários três requisitos: (i) descumprimento de um dever jurídico concreto de agir (omissão) ou cumprimento precário (ação) por parte do Estado ou de quem lhe faça às vezes; (ii) ocorrência de dano a um cidadão que não tenha o dever de suportar os seus efeitos; e (iii) nexo de causalidade entre o comportamento estatal e o prejuízo sofrido. ${ }^{94}$

A demonstração do nexo causal por ação estatal que gere dano, conforme exemplos ao final do item anterior, é mais simples e intuitiva, merecendo maior atenção aspectos teóricos nos casos de omissão no serviço de saúde.

Conforme defende Juarez Freitas, "o Estado-Administração brasileiro precisa, sem evasiva protelatória, compensar e, de preferência, evitar (com prevenção e precaução) os danos oriundos de toda e qualquer conduta administrativa desproporcional por excesso ou inoperância" ${ }^{\prime 95}$.

93 GABARDO, Emerson; HACHEM, Daniel Wunder. Responsabilidade civil do Estado, faute du service e o princípio constitucional da eficiência administrativa. In: GUERRA, Alexandre D. de Mello; PIRES, Luis Manuel Fonseca; BENACCHIO, Marcelo (Org.). Reponsabilidade civil do estado: desafios contemporâneos. São Paulo: Quartier Latin, 2010. p. 283.

94 HACHEM, op. cit., p. 1148.

95 FREITAS, op. cit., p. 16. 
A responsabilidade do Estado deve ser compreendida em conjunto com o direito fundamental à boa administração e qualquer recurso à reserva do possível deve ser feita com cuidado quando presente o nexo de causalidade (inexistência de excludente), levando-se em conta o princípio da proporcionalidade ${ }^{96}$.

A responsabilização patrimonial do Estado por omissão na área da saúde depende de um dever específico de agir que apenas pode ser constatado na análise do caso concreto, pelo dano ocorrido e pela demonstração do nexo causal entre a omissão estatal e o prejuízo ${ }^{97}$.

A falha anônima no serviço por omissão será objetivamente indenizável se, mediante ponderação de valores, for razoavelmente exigível a atuação estatal para evitar a lesão ${ }^{98}$. Ou seja, a responsabilidade por omissão no serviço de saúde pública é objetiva e tal entendimento vem gradativamente sendo aceito pela jurisprudência dos tribunais superiores ${ }^{99}$.

O direito à saúde e o dever estatal de prestar o respectivo serviço estão sumariamente previstos nos art. 196 a 200 da Constituição Federal, cabendo ao Poder Público a regulamentação por meio de lei, o controle e a fiscalização de procedimentos técnicos.

A Lei 8.080/1990 tratou em nível nacional sobre o assunto, em especial no Capítulo "Da assistência terapêutica e da incorporação de tecnologia em saúde" (art. 19-M a 19-U). O dever específico de agir suscetível de indenização em caso de omissão é aquele previsto em protocolo clínico e diretriz terapêutica elaborado Ministério da Saúde (art. 19-Q). Assim, como regra geral, se houve observância ao protocolo clínico, que é baseado em conhecimentos técnicos das ciências da saúde, não há que se falar responsabilidade do Estado, pois ausente o nexo causal entre o dano por caso fortuito ou força maior.

96 FREITAS, op. cit., p. 16. Rodrigo Valgas dos Santos afirma que "As omissões genéricas como o dever de segurança prestado pelo Estado aos seus cidadãos, em face da impossibilidade da onipresença estatal, em regra não conduzem a indenização, a exemplo dos assaltos em logradouros públicos não indenizáveis pelo Estado. Contudo, quando a conduta omissiva é específica, ou seja, decorre de omissão pontual e individualizada do Estado, pode haver a respectiva indenização, como por exemplo, a polícia rodoviária federal libera veículo sem condições de trafegabilidade por seu visível estado de má conservação e este vem a provocar acidente logo adiante, causando dano a terceiro". SANTOS, Rodrigo Valgas dos. Ibidem, p. 282. HACHEM, op. cit., p. 1148. GUERRA, op. cit., p. 310. 
Neste ponto, ressalta-se que a defesa da normatividade dos princípios, em especial dos direitos fundamentais em razão da sua aplicabilidade imediata, principalmente após a Constituição de 1988, não importa em desprestígio das regras, que conferem maior segurança jurídica ao ordenamento ${ }^{100}$.

Não se vislumbra inconstitucionalidade em abstrato dos dispositivos da Lei 8.080/1990, desta forma incide a "preferência pela lei [ou seja,] onde houver manifestação inequívoca e válida do legislador ela deve prevalecer, abstendo-se o juiz ou o tribunal de produzir solução diversa que lhe pareça mais conveniente" ${ }^{\prime 101}$.

Sendo a lei instrumento apto a regular e inclusive restringir direitos fundamentais, o dever específico de agir, indenizável em caso de omissão do ente estatal no serviço público de saúde, deve ter por pressuposto a legislação específica e demais atos normativos.

Eventualmente cabe impugnar os protocolos médicos por não incorporarem novos tratamentos ou por falta de motivação. Contudo, o ônus argumentativo será maior, pois a escolha de procedimentos e tratamentos pode se enquadrar no âmbito da discricionariedade do administrador, obrigado a optar por alternativas mais baratas com o objetivo de universalizar o serviço, deixando procedimentos mais caros para situações específicas. Por outro lado, inexistente o protocolo de tratamento, entra-se na esfera da aplicabilidade imediata dos direitos fundamentais, o que demanda uma resposta mais complexa mediante o necessário ônus argumentativo acerca do dever específico de agir do Estado na área de saúde.

Constatado dano decorrente da prestação de serviço público, é necessário se quantificar o valor indenizável com base na diligência média do serviço por meio de análise do caso concreto ${ }^{102}$, entendendo-se

\footnotetext{
100 SCHIER, Paulo Ricardo. Denúncia anônima em processo disciplinar na experiência dos tribunais superiores: entre os direitos fundamentais e o dever de investigação da Administração Pública. Revista de Direito do Estado. Rio de Janeiro, ano 4, n. 14, abr./jun. 2009, p. 16. Pertinente a exposição dos pressupostos adotados por Paulo Ricardo Schier acerca da incidência direta dos princípios: (i) a aplicação direta de princípios constitucionais em detrimento de regras infraconstitucionais revestidas de presunção de constitucionalidade (ou seja, sobre as quais não recaia um juízo de inconstitucionalidade evidente) é procedimento perigoso; (ii) há que se conferir uma certa deferência às decisões expressadas pelo legislador infraconstitucional em homenagem ao princípio democrático e à segurança jurídica; (iii) princípios, preferencialmente, devem ser aplicados através das regras que lhe dão concretude e expressam as opções da sociedade em relação às concepções dos conceitos trazidos por aqueles; (iv) logo, aplicação direta de princípios em detrimento de regras só pode ser levada a efeito com reservas e mediante a demanda de um ônus argumentativo mais custoso. Ibidem, p. 6.
}

101 Ibidem, p. 19.

102 HACHEM, op. cit., p. 1138. 
por diligência média a que atenda ao princípio da eficiência e ao direito fundamental à boa administração.

Segundo Daniel Hachem e Irene Nohara, o fundamento da responsabilidade patrimonial do Estado por atos omissivos é o princípio da igualdade, mais especificamente o princípio da igualdade dos cidadãos perante os encargos públicos. Os prejuízos sofridos pelo cidadão individualmente considerado por ineficiência no serviço público deve ser repartido na sociedade ${ }^{103}$. Esta foi a opção adotada pela Constituição, que não fez distinção entre ação ou omissão pública.

A fim de se constatar a ocorrência de uma omissão desproporcional, Juarez Freitas propõe os seguintes questionamentos: (i) a abstenção administrativa foi adequada ou negligenciou os meios eficientes e equitativos para a obtenção eficaz dos fins e objetivos constitucionais?; (ii) a abstenção administrativa foi necessária ou impôs sacrifícios iníquos, na distribuição dos encargos?; e (iii) no trade-off entre eficiência e equidade, o custo-benefício de abstenção foi justificável ou se tratou de abstenção de consequências injustificáveis? ${ }^{104}$

Constatado o dano, é necessário se verificar qual pessoa jurídica é responsável pela indenização. Em caso de ação a resposta é mais evidente, pois deverá arcar com a indenização o ente ao qual integra o órgão responsável. Em caso de omissão, em que pese a jurisprudência do Superior Tribunal de Justiça conferir responsabilidade solidária entre União, estados e municípios e legitimidade passiva para figurarem no polo passivo de demanda de saúde ${ }^{105}$ havendo regulamentação específica, não se pode ignorar a responsabilidade fixada pela Comissão Intergestores Tripartite, sob pena de negativa de vigência ao art. 19-U da Lei Orgânica da Saúde ${ }^{106}$. Leva-se a crer que a atual posição daquela corte tem por objetivo evitar a aplicação retroativa da Lei 12.401/2011, que incluiu referido dispositivo.

É importante ressaltar que o prazo prescricional para ajuizamento de ação de indenização, por tratar-se de serviço público de saúde, é de cinco anos, conforme art. $1^{\circ}-\mathrm{C}$ da Lei 9.494/1997.

\footnotetext{
103 HACHEM, op. cit., p. 790.

104 FREITAS, op. cit., p. 22.

105 BRASIL. Superior Tribunal de Justiça. Agravo Regimental no Agravo em Recurso Especial $n^{\circ}$ 712992/PR, Relator Ministro Napoleão Nunes Maia Filho. Julgado em 08.09.2015. DJe, publicado em 23.09.2015.

106 Art. 19-U da Lei 8.080/1990: "A responsabilidade financeira pelo fornecimento de medicamentos, produtos de interesse para a saúde ou procedimentos de que trata este Capítulo será pactuada na Comissão Intergestores Tripartite".
} 
A responsabilidade estatal tem por objetivo a neutralização dos danos, o retorno ao status quo como se o dano sequer tivesse existido ${ }^{107}$, motivo pelo qual alguns conceitos de Direito Privado, devidamente filtrados pelo regime jurídico de Direito Público, são necessários.

Conforme ressalta Bacellar Filho, a incidência do Direito Civil é subsidiária, ou seja, é aplicável apenas quando não houver norma específica de Direito Público ${ }^{108}$. Ainda, a aplicação do Direito Privado "depende de um juízo de conformidade e adequação com a Constituição Federal” ${ }^{109}$.

As modalidades de dano (moral, material, estético, lucros cessantes) e a indenização são aquelas previstas nos art. 944 a 954 do Código Civil, que admite o pagamento de quantia em parcela única à vítima ou a seus sucessores, pensionamento à vítima que tiver diminuição da sua capacidade de trabalho, aos seus dependentes em caso de morte ou inclusive aos pais da vítima de baixa renda, até a idade estimada de expectativa de vida dos genitores ${ }^{110}$.

"O dano ressarcível é aquele que se mostre especial, anormal e ofensivo a direito ou interesse legitimamente protegido"111. Os danos materiais podem ser mais facilmente demonstrados mediante perícia ou cotação de mercado. Por outro lado, em especial no cálculo do dano moral, não cabe considerar a reparação como sanção pecuniária dissuasiva, o conhecido efeito pedagógico ${ }^{112}$ aplicável principalmente do Direito do Consumidor.

No âmbito privado este critério é pertinente, pois o pagamento de indenização pelo reiterado descumprimento de determinado dever por vezes é mais vantajoso ao fornecedor que a solução definitiva da causa do dano.

Nos serviços públicos esta diretriz não deve incidir, com a ressalva aos concessionários privados prestadores de serviço público, pois o Estado não lucra com a atividade da saúde. Eventual repreensão à desídia reiterada da Administração deve se dar por ação civil pública ou outro meio cabível.

\footnotetext{
107 BACELLAR FILHO, op. cit., p. 233.

108 Ibidem, p. 195.

109 Ibidem, p. 198.

110 BRASIL. Superior Tribunal de Justiça. Agravo regimental no Recurso Especial $n^{\circ} 1325246$, Relator Ministro OG Fernandes. Decisão Monocrática, DJ, publicado em 08.05.2015.

111 BACELLAR FILHO, op. cit., p. 236.

112 MATTIETTO, Leonardo. A nova lei argentina de responsabilidade civil do Estado. Fórum Administrativo, Belo Horizonte, ano 15, n. 172, p. 108, jun. 2015.
} 
A responsabilidade estatal também não tem função punitiva, devendo ser arbitrado o dano moral com objetivo estritamente reparador.

Demonstrado o dano à saúde, que em geral será comprovado por atestados médicos, certidão de óbito ou outros meios, há que se verificar o nexo causal e a inexistência de excludente ou atenuante, quais sejam, fato da vítima ou de terceiro, caso fortuito ou força maior, impossibilidade razoável para o cumprimento do dever e estado de necessidade.

A observância dos procedimentos técnicos e do tratamento adequado ao diagnóstico na atuação da Administração importa na inexistência de nexo causal entre o dano e a conduta estatal por caso fortuito ou força maior na ocorrência do dano.

A partir deste ponto, com base na jurisprudência, é conveniente a exemplificação, apenas a título ilustrativo, de hipóteses de responsabilidade do Estado por ação ou omissão na prestação do serviço público de saúde.

Inexiste dever de indenizar se não for constatado erro médico ${ }^{113}$, isto porque o Estado teria responsabilidade com os meios, já que a medicina não é uma ciência exata, cada organismo pode reagir de maneiras diversas ao mesmo tratamento, logo incidem as excludentes do nexo causal do caso fortuito ou força maior em razão da imprevisibilidade do resultado da terapia.

Por outro lado, há responsabilidade estatal caso: o paciente contraia nova patologia durante o tratamento ${ }^{114}$; se constate negligência médica ao se esquecer compressa no interior do organismo após realização de cirurgiai ${ }^{115}$; ocorra lesão grave durante procedimento de parto ${ }^{116}$, pois há nexo causal entre a conduta estatal e o dano.

A demora injustificada na transferência de hospital por ambulância de paciente que resulte morte ${ }^{117}$ e no atendimento do Serviço de Atendimento

113 BRASIL. Superior Tribunal de Justiça. Agravo Regimental no Agravo em Recurso Especial n ${ }^{\circ} 664793$, Relatora Ministra Assusete Magalhães. Julgado em 28.04.2015. DJe, publicado em 08.05.2015.

114 BRASIL. Superior Tribunal de Justiça. Recurso Especial $n^{\circ}$ 1423483, Relator Ministro Humberto Martins. Julgado em 03.03.2015. DJe, publicado em 13.03.2015.

115 BRASIL. Supremo Tribunal Federal. Recurso Extraordinário com Agravo $n^{\circ} 788236$, Relator Ministro Gilmar Mendes. Julgado em 18.03.2014. DJe-057, divulgado em 21.03.2014, publicado em 24.03.2014.

116 BRASIL. Supremo Tribunal Federal. Agravo Regimental no Agravo de Instrumento $n^{\circ}$ 852237, Relator Ministro Celso de Mello. Julgado em 25.06.2013. DJe-176, divulgado em 06.09.2013, publicado em 09.09.2013.

117 BRASIL. Superior Tribunal de Justiça. Agravo Regimental no Recurso Especial $n^{\circ} 1341264$, Relator Ministro Olindo Menezes. Julgado em 18.06.2015. DJe, publicado em 29.06.2015. 
Móvel de Urgência - SAMU'118 é omissão que gera indenização, pois há dever específico de agir que poderia ter evitado o dano. A ineficiência estatal caracteriza o nexo de causalidade e a responsabilidade se dá com fundamento no princípio da igualdade na repartição dos ônus e encargos sociais.

Ocorre dano moral em caso de troca de resultados de exames ${ }^{119}$, pois há inobservância ao princípio da eficiência. Contudo, o Estado está isento de responsabilidade por realização de teste de HIV não solicitado que acusou resultado positivo ${ }^{120}$ pois não há nexo causal (fato da vítima ou terceiro) entre o dano e a conduta estatal.

A demora para marcar uma consulta médica importa em quebra do princípio da proporcionalidade e descumprimento de deveres constitucionais $^{121}$, logo gera dever de indenizar se houver dano ${ }^{122}$.

Por outro lado, não demonstrada a urgência do exame ou tratamento, não há dano a indenizar pela realização de exames na rede particular ${ }^{123}$ por ausência de dever específico de agir que ilide o nexo causal, pois o atendimento no serviço de saúde não é por ordem de chegada, sendo tolerável espera para atendimento por tempo razoável.

O fornecimento tardio ou a omissão na entrega de medicamentos que causem dano ao paciente, seja morte ou agravamento no seu estado, acarreta o dever de indenizar ${ }^{124}$. Seja em razão de decisão judicial ${ }^{125}$ ou medicamentos de fornecimento contínuo pela Administração, pois o descumprimento de um dever específico de agir caracteriza o nexo causal.

\footnotetext{
118 BRASIL. Tribunal de Justiça do Distrito Federal. Apelação cível no 20070111323007, Relator James Eduardo Oliveira. Julgado em 26.03.2014. DJe, publicado em 07.04.2014.

119 BRASIL. Superior Tribunal de Justiça. Agravo Regimental no Agravo Recurso Especial n 369613, Relator Ministro Humberto Martins. Julgado em 03.10.2013. DJe, publicado em 14.10.2013.

120 BRASIL. Superior Tribunal de Justiça. Recurso Especial $n^{\circ} 1195995$, Relatora Ministra Nancy Andrighi. Julgado em 22.03.2011. DJe, publicado em 06.04.2011.

121 FREITAS, op. cit., p. 21.

122 BRASIL. Superior Tribunal de Justiça. Agravo Regimental nos Embargos de Declaração no Recurso Especial $n^{\circ}$ 1263331, Relator Ministro Humberto Martins. Julgado em 18.10.2011. DJe, publicado em 26.10.2011.

123 BRASIL. Superior Tribunal de Justiça. Agravo Regimental no Agravo em Recurso Especial $n^{\circ} 497064$, Relatora Ministra Assusete Magalhães. Julgado em 19.03.2015. DJe, publicado em 26.03.2013.

124 FREITAS, op. cit., p. 22.

125 BRASIL. Superior Tribunal de Justiça. Agravo Regimental no Agravo Regimental em Recurso Especial $n^{\circ}$ 1292983, Relator Ministro Humberto Martins. Julgado em 01.03.2012. DJe, publicado em 07.03.2012.
} 
Hachem defende que adotando a responsabilidade objetiva por omissão haveria dever de indenizar por dano sofrido em razão da demora no atendimento médico decorrente de greve dos servidores da saúde ${ }^{126}$. Guerra, por outro lado, entende que poderia se tratar de caso fortuito, afastando a responsabilidade estatal ${ }^{127}$. Contudo, se a greve for considerada ilegal, há a possibilidade de ação regressiva (fato de terceiro), decorrente de dolo ou culpa, contra os agentes. Inclusive, pode-se cogitar responsabilização do próprio sindicato que declarou greve ilegalmente. Há também a posição de Eros Grau, que entende que os servidores na área da saúde não teriam direito à greve ${ }^{128}$, logo, nesta hipótese, haveria responsabilidade por dano ocorrido pela falha no atendimento.

\section{CONCLUSÕES}

Partindo-se do pressuposto da fundamentalidade e da universalidade do direito à saúde, bem como do dever do Estado de buscar todos os meios possíveis para garantir ao cidadão o mínimo existencial e um serviço público adequado, faz-se oportuno listar as principais conclusões apresentadas ao longo do trabalho.

1 A responsabilidade patrimonial do Estado na prestação do serviço público de saúde, seja diretamente ou por intermédio de particulares, tanto por ação quanto por omissão, é objetiva, ou seja, independe de demonstração de dolo ou culpa e se fundamenta no princípio da igualdade dos cidadãos perante os ônus e encargos sociais.

2 A fim de que o Estado não se torne segurador universal, a doutrina e a jurisprudência exigem a demonstração do nexo causal entre a conduta estatal e o dano, sem o qual não há dever estatal de indenizar.

3 Consideram-se excludentes do nexo causal, ou atenuantes em caso de culpa concorrente, o fato da vítima ou o de terceiro, o caso fortuito ou a força maior, a impossibilidade razoável para o cumprimento do dever e o estado de necessidade.

4 Nos casos de omissão, a fim de se verificar o nexo causal, é necessário a demonstração de um dever específico de agir do

126 HACHEM, op. cit., p. 1151.

127 GUERRA, op. cit., p. 318.

128 GRAU, Eros Roberto. A ordem econômica na Constituição de 1988. 17. ed. São Paulo: Malheiros, 2015. p. 223. 
Estado, que deve atuar com eficiência na prestação do serviço de saúde. A existência de protocolo clínico de tratamento, previsto na Lei 8.080/1990, é apto a comprovar a obrigação estatal.

5 Ressalta-se que o paciente não tem o direito subjetivo de escolher o tratamento a ser fornecido pelo Estado, que deve seguir os protocolos de tratamento expedidos pelo Ministério da Saúde. Se inexistente, é necessário recurso à aplicabilidade imediata do direito fundamental à saúde.

6 O ente estatal que causou o dano é obrigado a repará-lo. Em caso de omissão, o ente responsável é aquele fixado pela Comissão Intergestores Tripartite prevista no art. 19-U da Lei 8.080/90, a depender de quem tenha o dever específico de agir no caso concreto. Se não houver indicação do ente incumbido ou não puder ser determinado, a responsabilidade é solidária entre União, Estados e Municípios.

7 A extensão do dano material deve ser devidamente comprovado. Já o dano moral deve ser calculado com o estrito objetivo de reparar o dano, sem se atribuir à indenização função sancionatória ou pedagógica contra a Administração Pública.

\section{REFERÊNCIAS}

ALEXY, Robert. Teoría de los derechos fundamentales. Madrid: Centro de Estudios Constitucionales, 2007.

BACELlaR FILHO, Romeu Felipe. Direito Administrativo e o novo Código Civil. Belo Horizonte: Fórum, 2007.

BARCELLOS, Ana Paula de. Eficácia Jurídica dos princípios constitucionais: o princípio da dignidade da pessoa humana. 3 ed. revisada e atualizada. Rio de Janeiro: Renovar, 2011.

BARRETO, Vicente de Paulo. Reflexões sobre os direitos sociais. Revista Quaestio Iuris, [S.l.], v. 04, n. 01, p. 488-512, 2011.

BLASI, Marcos Chucralla Moherdaui. Panorama atual da responsabilidade do Estado em matéria de serviços públicos na jurisprudência do STF.

Revista Brasileira de Direito Público, Belo Horizonte, ano 8, n. 31 p. 91-125, out./dez. 2010. 
BRASIL. Supremo Tribunal Federal. Medida Cautelar na Arguição de Descumprimento de Preceito Fundamental $n^{\circ} 45$. Relator Ministro Celso de Mello, julgado em 29.04.2004. DJ, publicado em 04.05.2004.

BRASIL. Supremo Tribunal Federal. Recurso Extraordinário com Agravo $n^{\circ}$ 788236, Relator Ministro Gilmar Mendes. Julgado em 18.03.2014. DJe-057, divulgado em 21.03.2014, publicado em 24.03.2014.

BRASIL. Supremo Tribunal Federal. Agravo Regimental no Agravo de Instrumento $n^{\circ} 852237$, Relator Ministro Celso de Mello. Julgado em 25.06.2013. DJe-176, divulgado em 06.09.2013, publicado em 09.09.2013.

BRASIL. Supremo Tribunal Federal. Recurso Extraordinário $n^{\circ} 591874$, Relator Ministro Ricardo Lewandowski. Tribunal Pleno, julgado em 26.08.2009. DJe172, divulgado em 11.09.2009, publicado em 14.09.2009.

BRASIL. Superior Tribunal de Justiça. Agravo Regimental no Agravo em Recurso Especial $n^{0}$ 712992, Relator Ministro Napoleão Nunes Maia Filho. Julgado em 08.09.2015. DJe, publicado em 23.09.2015.

BRASIL. Superior Tribunal de Justiça. Agravo Regimental no Agravo em Recurso Especial $n^{\circ}$ 664793, Relatora Ministra Assusete Magalhães. Julgado em 28.04.2015. DJe, publicado em 08.05.2015.

BRASIL. Superior Tribunal de Justiça. Recurso Especial $n^{\circ}$ 1423483, Relator Ministro Humberto Martins. Julgado em 03.03.2015. DJe, publicado em 13.03.2015.

BRASIL. Superior Tribunal de Justiça. Agravo Regimental no Recurso Especial $n^{o}$ 1341264, Relator Ministro Olindo Menezes. Julgado em 18.06.2015. DJe, publicado em 29.06.2015.

BRASIL. Superior Tribunal de Justiça. Agravo Regimental no Agravo Recurso Especial $n^{\circ}$ 369613, Relator Ministro Humberto Martins. Julgado em 03.10.2013. DJe, publicado em 14.10.2013.

BRASIL. Superior Tribunal de Justiça. Agravo Regimental no Agravo em Recurso Especial $n^{\circ}$ 712992/PR, Relator Ministro Napoleão Nunes Maia Filho. Julgado em 08.09.2015. DJe, publicado em 23.09.2015.

BRASIL. Superior Tribunal de Justiça. Recurso Especial $n^{\circ} 1195995$, Relatora Ministra Nancy Andrighi. Julgado em 22.03.2011. DJe, publicado em 06.04.2011.

BRASIL. Superior Tribunal de Justiça. Agravo Regimental nos Embargos de Declaração no Recurso Especial $n^{\circ}$ 1263331, Relator Ministro Humberto Martins. Julgado em 18.10.2011. DJe, publicado em 26.10.2011. 
BRASIL. Superior Tribunal de Justiça. Agravo Regimental no Agravo em Recurso Especial $n^{\circ}$ 497064, Relatora Ministra Assusete Magalhães. Julgado em 19.03.2015. DJe, publicado em 26.03.2013.

BRASIL. Superior Tribunal de Justiça. Agravo Regimental no Agravo Regimental em Recurso Especial $n^{\circ} 1292983$, Relator Ministro Humberto Martins. Julgado em 01.03.2012. DJe, publicado em 07.03.2012.

BRASIL. Superior Tribunal de Justiça. Agravo regimental no Recurso Especial $n^{\circ}$ 1325246, Relator Ministro OG Fernandes. Decisão Monocrática, DJ, publicado em 08.05.2015.

BRASIL. Tribunal de Justiça do Distrito Federal. Apelação cível $n^{o}$ 20070111323007, Relator James Eduardo Oliveira. Julgado em 26.03.2014. DJe, publicado em 07.04.2014.

CALIENDO, Paulo. Reserva do possível, direitos fundamentais e tributação. In: SARLET, Ingo Wolfgang; TIMM, Luciano Benetti (org.). Direitos Fundamentais: orçamento e "reserva do possível". 2 ed. revisada e ampliada, Porto Alegre: Livraria do Advogado, 2013.

CLÈVE, Clèmerson Merlin. A eficácia dos direitos fundamentais sociais. In: BACELLAR FILHO, Romeu Felipe; GABARDO, Emerson; HACHEM, Daniel Wunder (Coord.). Globalização, direitos fundamentais e direito administrativo: novas perspectivas para o desenvolvimento econômico $e$ socioambiental: Anais do I Congresso da Rede Docente Eurolatinoamericana de Direito Administrativo. Belo Horizonte: Fórum, 2011.

FIGUEIREDO, Mariana Filchtiner; SARLET, Ingo Wolfgang. Reserva do possível, mínimo existencial e direito à saúde: algumas aproximações. In: SARLET, Ingo Wolfgang; TIMM, Luciano Benetti (org.). Direitos Fundamentais: orçamento e “reserva do possível”. 2. ed. revisada e ampliada. Porto Alegre: Livraria do Advogado, 2013.

FREITAS, Juarez. Omissão administrativa e o teste de proporcionalidade. Interesse Público, Belo Horizonte, ano 15, n. 78, p. 15-27, mar./abr. 2013.

GABARDO, Emerson. Responsabilidade objetiva do Estado em face dos princípios da eficiência e da boa-fé. In: FERRAZ, Luciano; MOTTA. Fabricio (Org.). Direito Público Moderno. Belo Horizonte: Del Rey, 2003.

GABARDO, Emerson; HACHEM, Daniel Wunder. Responsabilidade civil do Estado, faute du service e o princípio constitucional da eficiência administrativa. In: GUERRA, Alexandre D. de Mello; PIRES, Luis Manuel Fonseca; BENACCHIO, Marcelo (Org.). Reponsabilidade civil do estado: desafios contemporâneos. São Paulo: Quartier Latin, 2010. 
GLOECKNER, Joseane Ledebrum. A reserva do possível como limite à efetividade do direito fundamental à saúde. $A \mathcal{E}^{2} \mathrm{C}-$ Revista de Direito Administrativo \&ٔ Constitucional, Belo Horizonte, ano 13, n. 51, p. 233-250, jan./mar. 2013.

GOLON, Bruno Henrique; BORGES, Rosangela Mara Sartori. A responsabilidade civil objetiva do Estado e o Direito à saúde. Revista judiciária do Paraná, Curitiba, ano 9, n. 7, p. 207-227, maio 2014.

GRAU, Eros Roberto. A ordem econômica na Constituição de 1988. 17. ed. São Paulo: Malheiros, 2015.

GUERRA, Alexandre Dartanhan de Mello. Hipóteses de não incidência de responsabilidade civil do Estado. In: GUERRA, Alexandre Dartanhan de Mello; PIRES, Luis Manuel Fonseca; BENACCHIO, Marcelo (coord.). Responsabilidade civil do Estado: Desafios contemporâneos. São Paulo: Quartier Latin, 2010.

HACHEM, Daniel Wunder. Responsabilidade civil do Estado por omissão: uma proposta de releitura da teoria da faute du service. In: MARQUES NETO, Floriano de Azevedo; ALMEIDA, Fernando Dias Menezes de; NOHARA, Irene Patrícia; MARRARA, Thiago (Org.). Direito e Administração Pública: estudos em homenagem a Maria Sylvia Zanella Di Pietro. São Paulo: Atlas, 2013. p. 1131-1155.

- Mínimo existencial e direitos fundamentais econômicos e sociais: distinções e pontos de contato à luz da doutrina e jurisprudência brasileiras. In: BACELLAR FILHO, Romeu Felipe; HACHEM, Daniel Wunder (Coord.). Direito público no Mercosul: intervenção estatal, direitos fundamentais e sustentabilidade. Belo Horizonte: Fórum, 2013. p. 205-240.

A dupla titularidade (individual e transindividual) dos direitos fundamentais econômicos, sociais, culturais e ambientais. Revista de Direitos Fundamentais e Democracia, v. 14, n. 14, Curitiba, p. 618-688, jul./dez. 2013.

. Direito fundamental ao serviço público adequado e capacidade econômica do cidadão: repensando a universalidade do acesso à luz da igualdade material. $A \mathcal{E}^{2} C-$ Revista de Direito Administrativo $\mathscr{E}^{2}$ Constitucional, Belo Horizonte, ano 14, n. 55, p. 123-158, jan./mar. 2014.

LOPES, José Reinaldo de Lima. Em torno da reserva do possível. In: SARLET, Ingo Wolfgang; TIMM, Luciano Benetti (org.). Direitos Fundamentais: orçamento e "reserva do possível". 2. ed. revisada e ampliada, Porto Alegre: Livraria do Advogado, 2013. p. 155-173. 
MATTIETTO, Leonardo. A nova lei argentina de responsabilidade civil do Estado. Fórum Administrativo, Belo Horizonte, ano 15, n. 172, p. 107-112, jun. 2015.

MELLO, Celso Antônio Bandeira de. Curso de Direito Administrativo. 25. ed. São Paulo: Malheiros, 2008.

NOHARA, Irene Patrícia. Direito Administrativo. 5. ed. São Paulo: Atlas, 2015.

NOVAIS, Jorge Reis. Direitos sociais: teoria jurídica dos direitos sociais enquanto direitos fundamentais. Coimbra: Coimbra, 2010.

PIVETTA, Saulo Lindorfer. Direito fundamental à saúde: regime jurídico, políticas públicas e controle judicial. São Paulo: Revista dos Tribunais, 2014.

SANTOS, Rodrigo Valgas dos. Nexo causal e excludentes da responsabilidade extracontratual do Estado. In: FREITAS, Juarez (org.). Responsabilidade civil do Estado. São Paulo: Malheiros, 2006.

SARLET, Ingo Wolfgang. A eficácia dos direitos fundamentais: uma teoria geral dos direitos fundamentais na perspectiva constitucional. 10 ed. revisada, atualizada e ampliada. Porto Alegre: Livraria do Advogado, 2011.

. Algumas considerações em torno do conteúdo, eficácia e efetividade do direito à saúde na Constituição de 1988. Interesse Público - IP, Sapucaia do Sul, ano 3, n. 12, p. 91-107, out./dez. 2001.

SCHIER, Adriana da Costa Ricardo. Regime jurídico do serviço público: garantia fundamental do cidadão e proibição de retrocesso social. Curitiba, 2009. 224 f. Tese (Doutorado em Direito) - Programa de Pós-Graduação em Direito, Universidade Federal do Paraná, 2009.

SCHIER, Paulo Ricardo. Denúncia anônima em processo disciplinar na experiência dos tribunais superiores: entre os direitos fundamentais e o dever de investigação da Administração Pública. Revista de Direito do Estado, Rio de Janeiro, ano 4, n. 14, p. 3-23, abr./jun. 2009.

SILVA, Virgílio Afonso da. Direitos Fundamentais: conteúdo essencial, restrições e eficácia. São Paulo: Malheiros, 2009. 